\title{
NEW FACULTY ORIENTATION AND SEMINAR SERIES: EMPHASIS ON TEACHING AND LEARNING
}

\author{
William W. Predebon, Peck Cho, Diana George, Linda M. Ott, Philip Sweany \\ Michigan Technological University \\ Houghton, MI 49931-1295
}

\begin{abstract}
Traditional new faculty orientations focus on university services, fringe benefits, and research activities. If teaching is discussed at all, it is minimal. The orientation workshop and seminar series presented in this paper has a new look. The emphasis is on teaching. Topics discussed include: how to be a successful and happy faculty member, the Michigan Technological University (MTU) student body, total student development, university learning centers, and preparing for the first day. The orientation is followed by weekly seminars throughout the year. The weekly seminars, particularly in the fall, discuss just in time topics such as preparing for quizzes and exams, dealing with marginal student performance, student evaluations, classroom assessment, grading, active vs. passive learning, reflective teaching, etc. The orientation is directed at new faculty, i.e., faculty at the university for three years or less. The weekly seminar series includes more experienced teachers as well. The goal is to encourage an exchange of ideas about teaching between new and experienced professors.
\end{abstract}

The orientation and seminar series were initiated for the first time in Fall of 1995. The attendance, participation, and response has been very good. The evaluation and feedback from faculty in attendance has been encouraging.

\section{INTRODUCTION}

We did something new in the orientation for new faculty this year at Michigan Technological University (MTU). We supplied a focus for the orientation. Specifically, we focused the orientation on teaching at MTU. This is in sharp contrast to previous years in which the new faculty orientation involved representatives from various colleges and administrative departments each taking approximately half an hour to explain their function at the university. This year, we made a conscious decision to emphasize classroom practice in our faculty orientation.

There are several reasons why we felt it was important to focus faculty orientation around teaching issues. Possibly foremost is our belief that while new faculty members are bombarded with information about 


\section{Session 1275}

the need for publications and where and how to apply for funding, little attention is paid, at least initially, to sharpening teaching skills or even identifying classroom issues. New faculty often reach the conclusion that it's important to "get their research going first" and then worry about teaching later. We see several problems with this approach, and we hoped that by focusing orientation on teaching issues we could send a more balanced message about the University's expectations of new faculty. We also were responding to anecdotal evidence, both from new faculty and from students, that many first-year faculty are unprepared to teach and, in fact, don't know how to approach preparing for their first teaching experience. As one faculty member said, "I learned a great deal about how to do research while I was a graduate student, but I learned nothing about how to teach."

Given that new faculty orientation was to be focused on teaching, we identified several goals we wished to accomplish. These include:

ò We wanted new faculty to start thinking and talking about classroom practice from the time they first arrived on campus.

ò We wanted to provide some practical techniques that new teachers could use to organize and prepare their courses.

ò We wanted to make new faculty aware of the large body of research done in learning theory and applications of that research to classroom practice.

ò We wanted to investigate some issues of classroom practice in more detail than would be available in a two-day orientation workshop.

To meet these goals we settled on a two-part approach to faculty orientation. In the intensive two-day orientation workshop held shortly before the fall term began, we focused on developing an appreciation for the availability of research results with direct application to classroom practice as well as providing teaching "tips" to help new faculty with their first teaching assignment. In addition, we have held weekly one-hour seminars which focus on different teaching issues. This combined approach allowed time for in-depth investigation of different teaching methods as well as providing some help in getting started.

A few words about the faculty attendees are in order. Initially we expected that the majority of the new faculty attendees would be recent Ph.D.'s, i.e., earned their Ph.D. within a year of their first quarter at MTU. To our surprise this was not the case. About $50 \%$ of the 20 new faculty attendees were not first time teachers, i.e., they had varying amounts of teaching experience. As a result this dramatically affected the scope of the orientation and presentation of topics.

Also, some background information about Michigan Tech is relevant. The majority (> 80\%) of the MTU student body is either engineering (67\%), science, or technology. Consequently, the majority of the faculty are 


\section{Session 1275}

also in these fields. These are fields which traditionally don't educate Ph.D. students as teachers but rather as researchers or scientists. Further, the faculty in these disciplines are typically either unaware of or have had very limited exposure to the research in education theory, cognitive development, learning styles, etc. This provides the framework and background for the orientation workshop and seminar series presented in this paper.

\section{NEW FACULTY ORIENTATION WORKSHOP}

The first part of the new faculty orientation program at MTU was an intensive two-day workshop held shortly before fall quarter began. In addition to faculty new to MTU, faculty who have been at MTU for three (3) years or less were also invited to attend. One of the goals of the workshop was to expose new faculty to different parts of the campus early. MTU is a relatively compact campus so this is possible in a two-day workshop. To accomplish this, we moved the presentations around to different parts of campus which forced everyone to step out of their parochial environments and get to know MTU as a community instead of a series of isolated entities. Also, informal lunches and breaks were combined with the formal presentations to give the faculty a chance to get to know each other, establish networks, and to interact with the speakers.

The workshop focused on the following topics: successfully managing teaching as a faculty member, who are the MTU students, total student development, and preparation for teaching the first day.

Below is a brief description of the individual sessions.

SESSION I: How To Be A Successful And Happy Faculty Member

This session is divided into two sub-sessions. The first sub-session is on how to be successful, i.e., finding short-term success. It is about what faculty do and is activity-based. The second sub-session is on how to be happy, i.e., finding long-term success. It is about who faculty are and is emotion-based.

SESSION Ia: How To Be Successful

The objective of this session is to help faculty become "successful". The session shows (1) the criteria of success in terms of categories of activities and their relative values, both implicit and explicit, expected by MTU, (2) a healthy way to perceive and conceptually structure faculty's activities in meeting these criteria, and (3) the unity of faculty's activities from the perspective of student outcomes.

It included discussion of the following topics:

ò criteria for faculty success as stated by MTU administration

ò MTU faculty survey on teaching and research

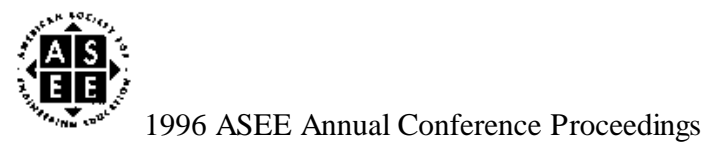


ò prevailing models on teaching vs. research1, 2

SESSION Ib: How To Be Happy

The main idea behind this session comes from a quotation, "He aimed for happiness, but settled for success." Hence, the objective for this session is to help faculty to attain "happiness," which is actually the "long-term success," as opposed to "short-term success" which was already discussed in the previous session. This session shows (1) the emotional aspect of the teaching process, (2) the management and "cultivation" of emotion, and (3) the recognition of the long-term effect of a good start.

It included discussion of the following topics:

ò Emotional basis of learning3

ò Axelrod's (1976)4 four teacher prototypes with their increasing level of emotional investment

ò $\quad$ MTU teacher evaluation form and policy

ò $\quad$ Attribution Theory applied to faculty in their teaching

ò Myths about teacher evaluations - facts and fiction

ò Characteristics of effective teaching5, 6

SESSION II: MTU Students and Learning Differences

The objective of this session is to access and address assumptions about students in order to discuss learning needs of MTU students. The topics in this session will help faculty to connect with the following: (1) teaching and learning are inseparable, (2) teachers can't teach students they don't know, and (3) the longer teachers teach, the more they tend to leave out because the material seems self-evident.

It included:

ò student assumption workshop with data on MTU students, including gender, race, and class differences

ò discussion of principles of good teaching practice7

SESSION III: Teaching To Enhance Total Student Development

The objective of this session is to help faculty become successful in student development. The session shows (1) different approaches towards development, and (2) the different resources faculty can use to aid in that development.

It included: 
Session 1275

ò discussion on approaches to student development - traditional and holistic

ò resources available on campus

ò areas of student concern, such as acceptance of diversity, faculty as role models, and sexual harassment issues

SESSION IV: University Learning Center Panel

This session involved a panel discussion by the coordinators of the five learning centers on campus. It was followed by a short question and answer period. These centers are where students can go to get assistance in fundamental courses, problem solving skills, and writing. The university centers are:

ò Chemistry Learning Center

ò $\quad$ Engineering Learning Center

ò Mathematics Learning Center

ò Physics Learning Center

ò Writing Learning Center

SESSION V: Preparing For The First Day

The objective of this session is to help faculty prepare for the first day of instruction and to give hints concerning course design, lesson preparation, and to discuss policies unique to MTU. It included:

ò preparing instructional objectives

ò developing course syllabi

ò starting the term - importance of the first and second day

ò designing your first course

ò preparation before the course starts

ò the lecture method

ò tips on questioning students

ò teaching aids and overhead tips

\section{SEMINAR SERIES}

Simply changing the focus of new faculty orientation will not do much to change the status of pedagogy across campus. Once the quarter or semester begins, issues raised in orientation are rarely a priority as new faculty struggle to find time to begin research projects, to learn and help do the business of the department, and to prepare new classes for a new student population. The pressures of beginning a university career, we would argue, too often make the talk of classroom practice infrequent and devalued. New faculty, in particular, take their cue from tenured colleagues and from university administrators. If there is little concern about ongoing 


\section{Session 1275}

discussion of classroom practice from those areas, there is likely to be little enthusiasm for it from new faculty.

In order to change that focus, we designed a series of ongoing faculty teaching seminars open to all faculty (tenured and not) and to all teaching assistants throughout the university. These seminars, scheduled throughout the school year, were meant to make talk of classroom practice a natural part of university business. By opening the seminars to all teaching faculty, we aimed to expose new faculty to the experience and enthusiasm of their tenured and tenure-track colleagues.

The seminar series, initially titled "Just In Time," consisted of Monday afternoon presentations, discussions, and workshops on issues that would help new faculty get through the year and touch upon themes of ongoing importance in classroom practice for all faculty. To that end, we offered discussions and workshops on such topics as classroom assessment, reflective practice, mid-term and final student evaluations, active vs. passive learning, and grading. One particularly animated and useful session was a panel presentation by several undergraduate and graduate students who talked anecdotally about what it was like to take classes at Michigan Tech. Without any prompting and even without consulting each other, the students managed to reinforce discussions the faculty had been having since orientation. In particular, they told the audience that students value faculty who take an interest in them and in the discipline they are teaching. They value active rather then passive learning techniques. They even encourage more frequent and varied ways of assessing their work. This panel, occurring near the end of the first term, gave faculty a chance to hear students' concerns and to see students as individuals vitally engaged in the business of learning. Up to this point, discussions had been about students but never with them.

The seminar series is continuing during the current winter quarter. Seminar topics that are ongoing or planned include learning and teaching styles, teaching portfolios, tips on balancing teaching and research, and the unprepared student. To continue to encourage talking about classroom practice we invited faculty to meet informally with us to continue discussions generated by the teaching seminars or to discuss any issues related to teaching. These meetings are planned for alternate weeks with the scheduled seminars.

\section{TIPS ON STARTING A SIMILAR PROGRAM AT ANOTHER INSTITUTION}

If you don't have such a program at your institution the following are some ideas and suggestions to help you get started. First of all you need support at the Dean's level and above, preferably up to the Provost. We cannot over emphasize the importance of the administration setting the tone that teaching and learning are valued and important for professional development (promotion, tenure, etc.) of new faculty. Some financial support is needed to develop the program. In our case the University had obtained a grant for this purpose which provided about a week of summer support money for each of the authors to develop the workshop and seminar series materials and some money for administrative and secretarial support and supplies. Having a team of faculty from different disciplines and colleges, including senior and relatively new faculty, to develop, oversee and evaluate the program, we found to be beneficial and rewarding. Consequently, we recommend 


\section{Session 1275}

having a "steering" committee to develop the program, which includes a balance of senior and relatively new faculty. It is also important to emphasize that the workshop itself is not enough. You need to have a program that continues during the academic year (our weekly seminar series) to investigate techniques in more depth, to set the "proper" tone that teaching/learning is important and to maintain a dialogue among the faculty and students to serve teaching/learning needs.

References 8 through 15 are recommended to help you get started. Finally, we recommend that you start early to develop a dialogue with other faculty members concerning teaching and learning.

\section{CONCLUSIONS}

For both the orientation workshop and seminar series the attendance, participation and response has been good. The evaluation from faculty on the orientation workshop has been good. Feedback from faculty participants has been very encouraging. One faculty attendee stated that "colleagues at other universities were amazed that MTU had a program and took the time and effort to work with new faculty on teaching." Another said, "the dual focus on 'Who Are The MTU Students?' and 'What Does It Take To Be A Good Or Great Educator?' was excellent. We plan to evaluate the entire program at the end of the seminar series in the spring quarter.

This project is still ongoing and will not be completed until the end of spring quarter. Through feedback from faculty attendees we have already incorporated some of their suggestions into the program and will continue to do so. We plan to continue the program next year and build upon our experiences thus far. Ultimately, we hope this will become a permanent part of the new faculty orientation at MTU and possibly elsewhere.

Finally, too often higher education is charged with caring far too little about the business of educating undergraduates. The focus in our colleges and universities, we are told, is on research dollars and high-profile scholarship rather than on solid pedagogy. It is true that most disciplines do not train Ph.D. students as teachers but rather as researchers and scholars. It is also true that teaching has been the one area of faculty performance notoriously difficult to evaluate. The experience of this team, however, indicates that university faculty, like other classroom teachers, will engage in useful talk about teaching and may even be eager for ongoing discussions of classroom practice.

\section{ACKNOWLEDGEMENT}

The authors would like to acknowledge the following people who contributed to the workshop: Nancy M. Grimm, Jean Blanning, Pamela A. Weht, Martha Y. Janners, Karla Lawton, Lois A. Blau, Dennis T.

Lewandowski, and John A. Jaszczak. This project was supported by the State of Michigan, Department of Education, Office of Equity 4S Grant. The authors also would like to acknowledge the support of Chris 


\section{Session 1275}

Anderson, Director, Educational Opportunity, MTU.

\section{REFERENCES}

1. P. MEYERS, "Teaching versus Research - Incompatibility or Overemphasis?" J. Eng. Educ., 82, 1, p32, 1993.

2. E.L. BOYER, "Scholarship Reconsidered: Priorities of the Professoriate," The Carnegie Foundation for the Advancement of Education, Princeton, NJ, 1990.

3. R. BREHLER AND J. SNOWMAN, "Psychology Applied to Teaching," 4th ed., Houghton Miflin, Boston, MA, 1982.

4. AXELROD (1976) in "On College Teaching" by K. Patricia Cross, J. Eng. Educ., 82, 1, p 9, 1993.

5. R. SPRINTHALL and N. SPRINTHALL, "Educational Psychology: A Developmental Approach," 3rd ed., Addison-Wesley, 1981.

6. K.A. FELDMAN, "The Superior College Teacher from the Student's View," Research in Higher Education, 5, 43-88, 1976.

7. A.W. CHICKERING and Z.F. GAMSON, "Seven Principles for Good Practice in Undergraduate Education," The Wingspread Journal, Seven Principles Resource Center, Winona State University, Winona, MN 1987.

8. T.A. ANGELO and K.P. CROSS, "Classroom Assessment Techniques," 2nd ed., Jossey-Bass Publishers, San Francisco, CA, 1993.

9. C.I. DAVIDSON and S.A. AMBROSE, "The New Professors Handbook," Anker Publishing Company, Bolton, MA, 1994.

10. P.C. WANKAT and F.S. ORCOVICZ, "Teaching Engineering," McGraw-Hill, Inc., 1993.

11. B.C. DAVIS, "Tools for Teaching," Jassey-Bass Publishers, San Francisco, CA, 1993.

12. The Teaching Professor, Magna Publications, Madison, WI, 1987 - present. 
13. R.F. MAYER, "Preparing Instructional Objectives," Fearon Publishers, Palto Alto, CA, 1962.

14. Taxonomy of Educational Objectives Handbook I: Cognitive Domain, B.S. Bloom, ed., David McKay, Inc., New York, 1956.

15. 147 Practical Tips for Teaching Professors, Magna Publications, Madison, WI, 1989.

\section{BIOGRAPHICAL INFORMATION}

DR. WILLIAM W. PREDEBON is Professor, Associate Chair, and Director of Graduate Studies in the Mechanical Engineering-Engineering Mechanics Department and Coordinator of the Engineering Learning Center at MTU. He recently co-developed a graduate Teaching Assistant training program at MTU. He has earned several teaching awards at MTU and has published in the area of self-paced instruction.

DR. PECK CHO is an Associate Professor in the Mechanical Engineering-Engineering Mechanics Department, the Director of the Engineering Learning Center, and the Interim Director of the Innovation Center at MTU. He is currently interested in injecting more creativity, entrepreneurship and industry perspective into the curriculum. He has received awards from MTU, the State of Michigan, SAE, ASEE, and NSF for his teaching and research.

DR. DIANA GEORGE is an Associate Professor of Cultural Theory and Composition Studies in the Department of Humanities, at MTU. She is the co-author, with John Trimbur, of the textbook Reading Culture, published by HarperCollins. Her work on composition pedagogy has appeared in College Composition and Communication, Journal of Teaching Writing and others. She currently directs the work of Teaching Assistants in the Department.

DR. LINDA M. OTT, an Associate Professor in the Computer Science Department at MTU since 1978, received her B.S., M.S., and Ph.D. degrees all in Computer Science from Purdue University in 1972, 1974 and 1978, respectively. Her current research interests are in software engineering, particularly software measurement.

DR. PHIL SWEANY, an Assistant Professor in the Computer Science Department at MTU since 1992, received a B.S. degree in Computer Science from Washington State University in 1983 and M.S. and Ph.D. degrees in Computer Science from Colorado State University in 1986 and 1992, respectively. His research interests are in computer optimization, parallelzing compilers, and parallel architectures. 